\title{
(Trans)Forming Gender: Social Change and Transgender Citizenship
}

\author{
by Sally Hines \\ Newcastle University \\ Sociological Research Online, Volume 12, Issue 1, \\ < http://uww. socresonline.org.uk/12/1/hines.htm/> \\ doi:10.5153/sro. 1469
}

Received: 26 Jan 2006 Accepted: 21 Nov 2006 Published: 31 Jan 2007

\begin{abstract}
This paper aims to contribute to recent sociological debates about gendered identity constructions and formations, and gendered citizenship, by exploring gender transformation through an analysis of new femininities and masculinities as they are variously articulated by transgender women and men.
\end{abstract}

The paper charts the ways in which transgender has emerged as a subject of increasing social and cultural interest in recent years. Shifting attitudes towards transgender people are also evident through recent legislative changes brought by the Gender Recognition Act (2005). These social, cultural and legislative developments reflect the ways in which gender diversity is acquiring visibility in contemporary society, and suggest that gender diverse people themselves are experiencing greater levels of social inclusion. Such developments mark transgender as an important and timely area of sociological study.

The paper argues that while the Gender Recognition Act marks a significant shift in socio-legal understandings of 'gender' as distinct from 'sex', it problematically remains tied to a medical perspective of transgender that continues to marginalise practices of gender diversity. The paper thus proposes caution against an assured trajectory of (trans) gender transformation and social change. Rather, normative binary understandings of 'gender' underpin recent social and legislative shifts, giving way to individual and collective tensions around the desirability of assimilation. In turn these issues produce divergent ways of living as 'new' women and men.

\section{Keywords: Citizenship, Identities, Gender, Gender Diversity, Gender Dysphoria, Gender Recognition Act, Medicalisation, Social Change, Surgery, Transgender}

\section{Introduction}

1.1 This paper aims to contribute to recent sociological debates about gendered identity constructions and formations, and gendered and sexual citizenship, by exploring citizenship debates within the context of the gender transformations of trans women and men. 'Transgender' is an umbrella term that includes transgender, transsexual, bigendered and intersex people, transvestites, cross-dressers, and drag kings and queens. 'Transsexual' refers to people who change their anatomical sex through hormones and/or surgery. In this paper the terms 'trans' and 'transgender' apply to individuals who have undergone hormone treatment or surgery to reconstruct their bodies, and to those who cross gender in ways which are less permanent.

1.2 First the paper will map the ways in which transgender has emerged as a subject of increasing social and cultural interest in recent years. This section will initially chart the 'cultural turn' to transgender and move on to address how shifting attitudes towards transgender people are evident through recent legislative changes brought by the Gender Recognition Act (GRA) (2005). Representing the civil recognition of gender transition, the GRA marks an important change in attitudes towards trans people; enabling the change of birth certificates and granting the right to marry. I will suggest that these social, cultural and legislative developments reflect the ways in which gender diversity is acquiring visibility in contemporary UK society. The paper will question, however, a linear reading, which positions these moves as evidence that gender diverse people as a whole are experiencing greater levels of social inclusion.

1.3 The second part of the paper develops this argument by examining transgender citizenship. This section first addresses conceptual understandings of citizenship, and moves on to explore how issues pertinent to transgender citizenship are 'medicalised', 'claimed' and 'transgressed'. The paper argues that 
transgender citizenship is both an uneven and contested terrain. I suggest that whilst some new forms of (trans) femininities and masculinities are benefiting from recent policy developments, other experiences and practices of gender transformation remain marginalised.

\section{Methodology}

2.1 Substantively the paper draws on recent empirical research to examine how issues central to current policy developments are understood and experienced by trans women and men in the UK. Rather than using interview material to present a research report, my intention in this paper is to use fieldwork to illustrate the conceptual concerns of the research. Research was completed at The University of Leeds between 2000 - 2004 as part of the ESRC research project 'Care, Values and the Future of Welfare' (CAVA). The aims of the research were to examine individual and collective transgender practices of identity and intimacy. Data was generated through two-stage in-depth interviews with thirty trans women and men in the UK over a nine-month period in 2002. 17 participants were trans women and 13 were trans men Participants were at different stages of transition, and the sample included people who use hormone therapy and/or a range of surgical modifications and those who reject such interventions. Participants' decisions about the use of body modification practices can be seen to be indicative of their personal transgender identity construction. Whilst hormone and surgical interventions cannot be smoothly analysed as representative of a transsexual/transgender binary, and, indeed, many participants who identified as transgender used hormones, nevertheless, as the following empirical sections of the paper suggest, there is a substantive difference between the trans identities of those who use surgical modifications and those who do not. While some participants chose to use their own names, others adopted pseudonyms. Interviews took between one and two hours, and most interviews took place in participant's homes.

2.2 Interviews were used as a means through which to explore the social world of participants (Blaikie, 2000). Rather than approaching the interview method as a means to a 'fixed' text, which reveals 'true' meaning, I followed Plummer (1995) in viewing narratives as socially constructed and socio-historically specific. I was influenced by Hollway and Jefferson's (2000) 'narrative approach', which moves beyond a 'question and answer' interview style and allows the interviewer to flexibly respond to the narrator. One of the central characteristics is that questions are open -ended so that 'stories' may be told. In the course of the research, I asked people questions about some of the most intimate aspects of their lives. Sexuality was a key topic, and I also asked about bodily changes and surgery. I asked questions about participants' close relationships, which, for some, touched on difficult experiences with friends, families, partners and children. Ethical considerations were thus paramount throughout the research. I followed Hollway and Jefferson's criteria for social researchers in which 'the ethical principles of honesty, sympathy and respect would be central' (2000:102). I was aware that the particularly sensitive nature of researching transgender issues demanded that I remain 'extra aware' of ethical considerations. Transphobia leads to violence, hostility and the loss of jobs, homes and custody of children. Whilst all participants were open about their identities to some extent (if they had not been they would not have agreed to be involved in the research), this differed in degrees. On the ethics of researching transgender, I was influenced by Griggs (1998) and Cromwell (1999) who stress the importance of avoiding misrepresentation. The ethical issue of researching transgender issues as non-transgender person carried the additional concern of misrepresentation. In this respect, I followed the guidelines laid out by Hale (1997) for non-transgender people working on transgender.

2.3 As a non-transgender researcher, I had anticipated difficulty in gaining access to research participants, however, this was not the case and I was unable to interview all the people who contacted me. The large response to requests for participants led me to wonder, and to ask, why people wanted to participate. The most common reason concerned the social awareness of transgender issues and experiences. The representation of transgender people - especially in popular media and journalism - was associated with misconceptions of 'who' transgender people 'were' and, in turn, to discrimination on both a social (i.e. hostility on the street) and a political (i.e. lack of legal recognition of gender of choice) level. Involvement in the research was linked to dynamics of social and political change as participants spoke of 'speaking out' and of trying to 'put the record straight'. Here we can see an understanding of knowledge as a vehicle for social change. This connects with Plummer's (1995) discussion of story telling as a political process and illustrates how story telling may be used by previously disenfranchised communities to assert their growing strength. In this way, it is significant that the timing of the research coincided with initial legislative proposals representing the civil recognition of transgender people. Plummer's model for understanding the social construction of story telling incorporates the 'cultural and historical level', which denotes the specific historical moment in which a story is told and heard. Plummer notes that 'many stories are in silence dormant, awaiting their historical moment' (1995: 35). Perhaps the large response to this research, then, can be seen as an indication that the 'historical moment' has arrived for some transgender individuals.

2.4 My position as a non-transgender researcher will have affected the outcome of the research, although it is not possible to know to what extent. Common experiences between researcher and participants have 
been seen to positively affect the levels of trust in an interview, and thus to significantly impact upon the emerging data (Dunne, 1997;Oakley, 2000. A transgender researcher may have benefited from an 'insider' position to build trust with potential participants. This could have given her/him access to people who might not have replied to my requests for participants, which clearly stated my position as a non-transgender person. A transgender researcher might also have had 'inside' knowledge, which could have led her/him to ask different questions. Two personal contacts were invaluable in providing a 'way in' on occasions where I directly contacted particular participants; thus acting as a starting point for the development of trust in these instances. Weeks et al (2001) importantly caution against overemphasising areas of commonality between respondents and researchers, and follow Edwards (1993) and Song and Parker (1995) in addressing how other differences are always at play. Yet I recognise that the research can only be a partial study and that my non-transgender status (as it affected the research design as well as the research process itself) is built into that partiality.

\section{The Turn to Transgender}

\section{The Cultural Turn}

3.1 In recent years transgender has emerged as a subject of increasing social and cultural interest. Popular representations of transgender are apparent in TV drama, sitcom and reality TV, whilst the "trans confessional' is a chat show staple. Tabloid journalists and magazine feature writers increasingly search for trans people for 'real life' stories, and television documentary and broadsheet journalism has focused upon the experiences of both female and male trans people. Transgender characters have had central roles in several mainstream films, and on-stage, cross-dressing performers such as Eddie Izzard, Lilly Savage and RuPaul draw large audiences. Whilst I do not wish to over-prioritise the political significance of such cultural representations - and indeed many barely move beyond stereotypes - cultural representations can give an indication of how minority gender and sexual identities are able to shift to some degree beyond their marginalised status. In 2004, for example, artist Grayson Perry won the Turner Prize for his multi-media artwork which explores his transvestite persona Claire. In the same year, the most wide- reaching cultural representation of transgender arose from the reality television show Big Brother 5, whose housemate and winner was twenty-seven year old trans woman Nadia Almada. In and out of the Big Brother house, Nadia received extensive television and newspaper coverage, leading Observer columnist Barbara Ellen to comment that: 'The triumph of a Portuguese transgender woman in the nation's greatest unofficial popularity contest threw up important questions about Britain today. Are attitudes shifting? Is there a greater tolerance and broadmindedness, at least among the nation's youth?[...]'(2004).

3.2 For Christine Burns of transgender political lobbying group and educational organisation Press for Change (PfC), Nadia has emerged as an unlikely role model: 'I never in my wildest dreams imagined that after all these years it would be a big-breasted golden-hearted Portuguese nicotine junkie who really turned people's ideas about us upside down' (2004). Similarly, Lynne Jones, MP and Chair of the Parliamentary Forum on Transsexualism, says: 'The Big Brother result indicates people haven't got the kind of prejudices that would in the past have prevented them voting for a transsexual housemate. They're just voting for her as a woman in her own right. The fact of her being transsexual is not important' (2004). Both Burns and Jones optimistically suggest a cultural sea-change in attitudes towards transgender people. Against the backdrop of the Gender Recognition Act (GRA), then, it might be tempting to deduce that citizenship rights for trans men and women have now been gained.

\section{The Legislative Turn}

3.3 Before the Gender Recognition Act (2004) Britain was one out of four European countries that failed to legally recognise the acquired gender of transsexual people (Whittle, 2000: 44). In enabling trans people to change their birth certificates and to marry, the GRA marks a dramatic shift in socio-legal attitudes. Read alongside the cultural milieu, the GRA suggests that gender diversity is acquiring visibility in contemporary society. This has been welcomed by transgender organisations and individuals as a marker of increased tolerance. The transgender campaigning organisation Press for Change (PfC) was instrumental in setting up the cross-party Parliamentary Forum on Transsexualism and, for a decade, worked closely with government on drafting and amending the Bill. For PfC, the GRA is highly significant: 'The Gender Recognition Act is a crucial step towards ending 33 years of social exclusion for trans people in the UK' (http://www.pfc.org.uk homepage). Indeed, for many trans people the GRA is momentous; as the following quotation from a letter posted on PfC's website testifies: 'This morning I received an envelope containing a document, which I have been longing for over a length of time bordering forty years. To say that I am happy is the understatement of the century [...] (http://www.pfc.org.uk).

3.4 Whilst I do not wish to diminish the significance of the GRA, unpacking current debates about transgender citizenship calls for caution against a perceived trajectory of progress in relation to (trans) 
gender transformation and social change. Normative binary understandings of gender that underpin the legislation mean that some trans people are excluded from these new citizenship rights, whilst others remain unrecognised. Moreover, debates around the desirability of assimilation suggest that understandings and experiences of social citizenship are complexly situated.

\section{Conceptualising Citizenship}

4.1 The concept of citizenship gained academic capital during the 1980s and 1990s and was articulated as a means through which to stress the importance of political activity (Phillips, 1993). Citizenship has been broadly defined as the collection of rights and responsibilities that establish political membership and enable access to benefits and resources (Turner and Hamilton, 1994). Though dominant western notions of citizenship have traditionally followed a liberal model in which individual rights are stressed alongside minimum state intervention and market freedom (Marshall, 1950), citizenship is a contested concept, which is culturally and historically specific. Whilst neo- conservatives argue that the balance between rights and duties is weighted too heavily in favour of the former, radical critics have variously pointed to how the rights of dominant social groups are protected at the expense of marginal groups (Turner and Hamilton, 1994).

4.2 Such perspectives stress the need to broaden the concept of citizenship to take greater account of the social positioning of minority groups. Work on citizenship and ethnicity (Lewis, 1998, Back and Solomos, 2000), for example, has illustrated how traditional models of citizenship have failed to acknowledge ethnicity and nationality; whilst feminist work on citizenship has drawn attention to the ways in which women's interests have been neglected by a traditional model of citizenship that focused upon the 'public' (paid labour) rather than the 'personal' (domestic), thus marginalising women's interests in the latter - for example, in unpaid caring work (Lister, 1997). Feminist scholars have challenged traditional assumptions of the citizen as male (Pateman, 1989; Walby, 1994, Lister, 1997, Bussemaker and Voet, 1998, Daly and Cowen, 2000). Lister (1997) draws attention to the ambiguities of citizenship for feminism - on the one hand citizenship offers the possibility of universal rights, which are central to feminist goals, yet historically women have been excluded from citizenship debates, and inequalities remain. As Monro argues: 'Inequalities persist despite support for formal equality in many countries, partly because mainstream notions of citizenship continue to be based on implicit assumptions that citizenship means the same thing for women and men, masking differences in their interests. Current notions of citizenship still hide gender inequality' (monro 2000:150).

4.3 Writers within sexuality studies (Evans, 1993; Cooper, 1995; Plummer, 1995; Weeks, 1995, 1998; Seidman, 1998; Bell and Binnie, 2000; Richardson, 1998, 2000; Weeks et al, 2004) have also addressed how traditional models of citizenship mask difference; in this instance to marginalise the experiences and discriminate against the rights of those who variously live outside the hetero norm. Thus traditional notions of citizenship imply heterosexuality so that the domain of citizenship itself is heterosexualised (Richardson, 1998). The concept of 'sexual citizenship' has been developed to draw attention to sexuality, which has been excluded from the 'public' notion of citizenship. In the first discussion of 'sexual citizenship', Evans (1993) maps the relationship between sexuality, morality and the capitalist market. He argues that the process of 'consumer citizenship' enables capitalism to detach morality from legality. In order for the state to capitalise on the economic power held by some sexual minority groups, for example, middle class gay men, legal rights are granted at the expense of political rights. For Evans, 'consumer citizenship' has led to the commodification of sexuality, which looses its political edge through the branding of sexual identity as 'lifestyle'. Whilst the 'male homosexual citizen' holds economic rights, he remains an 'immoral' citizen. Moreover, sexual minorities who hold little obvious economic capital, for example, bisexuals and transvestites, are marginalised and granted neither economic or political citizenship (Evans, 1993).

4.4 For Richardson (2000a) the notion of sexual citizenship articulates the sexual rights, alongside wider rights and their impact on sexuality, in recognition of sexual minorities; while Weeks (1998) contextualises sexual citizenship in relation to broader social shifts. Weeks (1998) identifies the prerequisite of sexual citizenship as the respect for diversity and the consideration for the claims of minority groups. He positively suggests that these requirements are insight; pointing to the democratisation of sexual relationships, an increased reflexivity about sexuality and the emergence of new sexual subjectivities in contemporary society. Others, however, are less optimistic. Richardson argues that the granting of lesbian and gay rights leads to the privatisation and circumscription of these sexual identities: 'lesbians and gay men are granted the right to be tolerated as long as they stay within the boundaries of that tolerance [...] (1998: 90). Since notions of citizenship are heterosexualised, such boundaries of tolerance depend upon rights based claims (such as the right to marry), which fit with a heterosexual model of the 'good citizen'. For this reason Stychin points to the perils of articulating lesbian and gay rights through the concept of citizenship: '[ ... [lesbians and gays seeking rights may embrace an ideal of "respectability", a construction that then perpetuates a division between "good gays" and (disreputable) "bad queers"' (1998: 2000). It is the latter 
who are excluded from notions of citizenship. Similarly, Bell and Binnie (2000) suggest that sexual citizenship implies a set of 'rights based' claims, for example, the right for lesbians and gay men to marry and to serve in the military, which, in turn, entails a set of duties; notably the duty to assimilate. This constructs a binary between the 'good homosexual' (the assimilator) and the 'bad homosexual' (the dissident), with the former being granted citizenship: 'The effect of this manoeuvre on activist strategies can be to surrender some 'rights' for the sake of others. This means that agitating under the banner of sexual citizenship is always going to involve potential compromise' (Bell, 2004: 204). Bell and Binnie propose 'queering' citizenship to acknowledge and celebrate the ways in which non-normative sexual practices and arrangements (for example, non-monogamy) challenge the institution of heterosexuality and traditional conceptualisations of citizenship.

4.5 A further way in which the relationship between sexuality and citizenship has been considered is through the notion of 'intimate citizenship' (Plummer, 1995; Weeks, 1998; Weeks et al, 2001), which offers a framework for discussing rights and responsibilities emerging from the diversification of intimate life. Plummer (1995) defines 'intimate citizenship' as the rights concerning people choices about their bodies, emotions, relationships and desires, and proposes adding 'intimate citizenship' to the traditional models of political, social and civil rights. For Weeks, intimate citizenship concerns 'those matters which relate to our most intimate desires, pleasures and ways of being in the world' (1998: 121).

4.6 Together, work on feminist, sexual and intimate citizenship has addressed how traditional definitions and requirements of citizenship have neglected the complex features of gender and sexuality (Richardson, 2000a). Broadening the notion of citizenship in this way enables the recognition of difference and problematises the public/private dichotomy. Yet this work largely assumes a gender binary that acknowledges only male and female categories. Importantly Monro $(2003,2005)$ has brought to light the ways in which existing models of citizenship work within a gender binary system that presumes the citizen is either male or female. A gender binary model of citizenship has discriminated against gender diverse people in terms of the 'public' (employment and welfare rights) and the 'private' (the rights of selfidentification in gender of choice and of partnership recognition). The GRA is important in enabling such processes of self-identification.. Additionally, employment and welfare rights for trans people increasingly occupy a place on the public agenda. Such moves represent a dramatic shift in conceptual understandings of 'gender' as distinct from 'sex' (Butler, 1994), and indicate how feminist scholarship has entered the mainstream public and political agenda. Rather than biological 'sex' being the fixed marker of identity, 'gender' recognises that identity is more fluidly experienced and articulated. However, whilst the structural framework of the gender binary model of citizenship has flexed to concede that a person may change her/his gender, the male/female poles of the structure remain firmly intact. The effects of this bear down not only on the rights afforded to gender different people but also on a more profound level, which impacts upon self-identification. As I will move on to explore, a gender binary model of citizenship continues to marginalise both the experiences and subjectivities of those who cannot or will not define as 'man' or 'woman', and, as such, is unable to account for the full spectrum of gender diversity.

\section{Medicalising Transgender}

5.1 Medical and psychological studies have constructed particular ways of thinking about gender diversity, which continue to inform social, cultural and legal understandings of transgender. The theoretical shifts that accompanied the increasing acceptance of reconstructive surgery from the late 1950s onwards strengthened the role of the medical practitioner. Benjamin's Transsexual Phenomenon (1966), Stoller's Sex and Gender(1968) and Green and Money's Transsexualism and Sex Reassignment (1969) introduced the notion of 'gender' into discourses of transsexuality, and 'gender' came to be recognised independently of 'sex'. As Ekins and King explain: 'If gender is immutable, even though psychologically produced, and if harmony between sex and gender is a precondition of psychic comfort and social acceptability, it 'makes sense' to achieve harmony by altering the body' (1996: 94). Thus it was believed that surgery enabled the 'true' self to emerge and most practitioners aligned with this narrative. From the early 1970s, the concept of 'gender dysphoria' was developed in medical writing. 'Gender dysphoria' suggests that those seeking hormone therapy or surgery have been born, and so are living, in the 'wrong' body.

5.2 By the late 1970s, surgical procedures had become the orthodox method of 'treatment' for gender dysphoria (Cromwell, 1999). Contemporary medical perspectives continue along a biologically based line as the 1996 report for the UK Parliamentary Forum on Transsexualism illustrates: 'The weight of current scientific evidence suggests a biologically based, multifactoral aetiology for transsexualism' (Transsexualism: The Current Medical Viewpoint, 1996). Though later medical insights represent a more complex understanding of transgender practices than were offered within founding medical perspectives, there remain serious problems in the correlation of transgender and biological or psychological pathology. The epistemological power of medical discourse has thus worked to structure specific aetiologies of transgenderism. Significantly, the concept of 'gender dysphoria' remains a key classificatory term within 
medical discourse and practice. The GRA marks a significant shift in socio-legal understandings of 'gender' as distinct from 'sex' and, importantly, gender reassignment surgery is not a requirement of gaining gender recognition. Yet the Act is shaped by a medical perspective of transgender that privileges a connective relationship between gender identity and body parts and presentation. PfC's advice on seeking gender recognition under the GRA states: 'If you can demonstrate reasonable evidence that you have undergone "surgical treatment for the purpose of modifying sexual characteristics" (i.e. surgery to alter the shape and function of genitals) then this is by far the easiest way to apply [...]The alternative way in which the law allows an application to be accepted by the panel is if you can provide evidence of having being diagnosed with "gender dysphoria"' (http://www.PfC.org.uk). From its inception in the 1970s, then, the concept of 'gender dysphoria' has guided understandings of, and practices towards, transgender. Therefore, it is not surprising that the central tenet of the concept - dissonance between sex (the body) and gender identity (the mind) - figures large in many trans narratives. Research participant Bernadette reflected this in reply to my question 'what are the most important changes transition has brought?':

Before I transitioned, I had become terrified of mirrors. I couldn't look at myself. I was absolutely horrified looking at myself and this was completely resolved. [...] These are the things which have changed, and made me feel what I am. They are the external manifestations that balance.

\section{(Bernadette, Age 71)}

5.3 Corresponding with the concept of 'gender dysphoria', Bernadette positions her pre-transition body as the 'wrong' vehicle in which her essential self was trapped. Surgical 'correction' is subsequently related as the means through which her authentic gender is released. In her discussion of MtF autobiography, Stone shows how accounts of the 'wrong body' lie at the heart of many personal accounts of transition: 'They go from being unambiguous men, albeit unhappy men, to unambiguous women. There is no territory between. Further, each constructs a specific narrative moment when their personal sexual identification changes from male to female. This moment is the moment of neocolporraphy - that is, of gender reassignment or "sex change surgery" ' (1991: 286). Such an account is oppositional to a poststructuralist framework and to queer theory, in which all gender and sexual identities are denaturalised and notions of authenticity deconstructed. Much debate within transgender studies has been concerned with addressing the contradictions between a deconstructionist analysis of transgender and the representation of a fixed identity within many transgender autobiographies. Thus a key question for Prosser (1998) is how to theorise sex, gender and identity in the light of continued transsexual demand for reconstructive surgery. He suggests that the 'wrong body' narrative reflects a genuine transsexual emotion, which he discusses as the desire for an embodied 'home':

My contention is that transsexuals continue to deploy the image of wrong embodiment because being trapped in the wrong body is simply what transsexuality feels like. If the goal of transsexual transition is to align the feeling of gendered embodiment with the material body, body image- which we might be tempted to align with the imaginary-clearly already has a material force for transsexuals. The image of being trapped in the wrong body conveys this force. It suggests how body image is radically split off from the material body in the first place, how body image can feel sufficiently substantial as to persuade the transsexual to alter his or her body to conform to it. The image of wrong embodiment describes most effectively the experience of pre- transition (dis)embodiment: the feeling of a sexed body dysphoria profoundly and subjectively experienced.

(1998: 69, my emphasis)

5.4 Yet it has been widely acknowledged that, in order to gain access to hormone therapy or surgical procedures, trans people frequently reproduce the officially sanctioned aetiology of transsexualism; that of gender dysphoria (Green, 1987; Stone, 1991; Hausman, 1995; Bolin, 1998; Cromwell, 1999). Indeed, in the 1970s, Stoller acknowledged this process, remarking: 'Those of us faced with the task of diagnosing transsexualism have an additional burden these days, for most patients requesting 'sex change' are in complete command of the literature and know the answers before the questions are asked' (Stoller, 1975: 248). Subsequently, medical professionals have suggested that trans people may 'distort their autobiographies (and) tend to be less than honest about their personal histories' (Lothstein quoted in Cromwell, 1999: 124). As Stone remarks: 'This raises several sticky questions, the chief two being: Who is telling the story for whom, and how do the storytellers differentiate between the story they tell and the story they hear?'(1991: 291). Thus the 'wrong body' narrative may be seen to be medically constructed and internalised as a means to an end: 'The idea has been imposed upon transpeople by those who control access to medical technologies and have controlled discourses about transpeople. Some individuals may believe or come to believe that they are in the wrong body or at least use language that imparts the same meaning [...]' (Cromwell, 1999: 104). In the following quotation from our interview, Gabrielle illustrates how 
G If you see a doctor for an hour once every three months and they go 'how are you?' and you go 'I'm fine'. And they go 'any issues?' you go 'no'. 'Cos you want what they've got to give you and so you quickly learn the script as people call it, for what you should say and not say. And I think people buy into that, people do say these things that the doctors need to hear to tick off on the form to make you eligible.

\section{S And what are those things?}

G 'I'm a woman trapped in a man's body' or 'A man trapped in a woman's body'. 'I've known always', you know, those sort of things, the things that people say.

\section{(Gabrielle, Age 45)}

5.5 Gabrielle's narrative connects with Shapiro's argument that 'One cannot take at face value transsexuals' own accounts of a fixed and unchanging (albeit sex-crossed) gender identity, given the immense pressure on them to produce the kinds of life histories that will get them what they want from the medical-psychiatric establishment' (quoted in Nataf, 1997: 19). The extent to which trans people continue to research diagnostic guidelines is illustrated in the Harry Benjamin 'Standards of Care', which formulate the 'professional consensus about the psychiatric, psychological, medical, and surgical management of gender identity disorders' (The Harry Benjamin International Gender Dysphoria Association's Standards of Care for Gender Identity Disorders: Version Six, 2001) The document details the means by which trans people may find 'new gender adaptations'; stating that 'both genders may learn about 'transgender phenomena from studying these Standards of Care, relevant lay and professional literatures about legal rights pertaining to work, relationships, and public cross-dressing' (The Harry Benjamin International Gender Dysphoria Association's Standards of Care for Gender Identity Disorders, Version Six, 2001).

5.6 Questions around the impact of a medical model on trans subjectivities brings to mind Foucault's writing on the body. For Foucault, the body is constructed through power: 'The body is directly involved in a political field; power relations have an immediate hold upon it; they invest it, mark it, train it, torture it, force it to carry out tasks, to perform ceremonies, to emit signs' (1977: 25). Thus subjects are produced through discourses of the body. Complicity with a medical model of transgender both supports and paradoxically challenge Foucault's notion of the 'docile body', which is a 'direct locus of control' produced by external power. Thus whilst the 'wrong body' hypothesis can be seen as a discourse that produces its subject, the self-conscious repetition of the 'wrong body' narrative can be read as an agency driven process whereby trans people employ knowledge as power. Foucault's later work is more relevant to this interplay between structure and agency. In discussing 'techniques of the self' (1985), Foucault creates a space for agency by examining the relationship between external power and subjectivity. From this point, the notion of the 'wrong body' can be conceptualised as a rehearsed narrative that is consciously repeated as a means to an end. Yet rehearsed narratives are not only characteristic of transsexual stories, as Shapiro acknowledges: 'To take the problem one step further, the project of autobiographical reconstruction in which transsexuals are engaged, although more focused and motivated from the one that all of us pursue, is not entirely different in kind. We must all repress information that creates problems for culturally canonical narratives of identity and the self, and consistency in gender attribution is very much a part of this' (quoted in Nataf, 1997: 19).

5.7 Stone argues that the 'wrong body' narrative has led to the invisibility of transsexualism as an identity in itself: "The highest purpose of the transsexual is to erase him/her, to fade into the "normal" as soon as possible...What is gained is acceptability in society. What is lost is the ability to authentically represent the complexities and ambiguities of lived experience [...]' (1991: 295). She proposes that analyses of transgender move away from the 'wrong body' paradigm in order to negotiate 'the troubling and productive multiple permeabilities of boundary and subject positions that intertextuality implies' (1991: 297). Halberstam also problematises the 'wrong body' diagnosis: 'Who, we might ask, can afford to dream of a right body? Who believes that such a body exists?' Many bodies are gender strange to some degree or another, and it is time to complicate on the one hand the transsexual models that assign gender deviance only to transsexual bodies and gender normativity to all other bodies, and on the other hand the heteronormative models that see transsexuality as the solution to gender deviance and homosexuality as a pathological perversion' (1998: 154-155). Halberstam argues that Prosser's analysis depends upon a strict demarcation of gender: 'it relies on a belief in the two territories of male and female, divided by a flesh border and crossed between surgery and endocrinology' (1998: 164). Prosser's focus may thus be critiqued for implying that all transsexual narratives are alike and, moreover, for denying instances of gender dysphoria within other subject positions (trans and non-trans). His emphasis may also work against the interests of trans people by further pathologising their 'condition' through reinstating the duel categories of 'wrong' (trans) and 'right' (non-trans) bodies. For many participants in my research, the 'wrong body' narrative was deeply unsatisfactory, and trans identification was discussed as a more complex and 
nuanced process. I asked Rebecca how she felt about the 'wrong body' metaphor:

It's [transition] been a progression. It's never been fixed from the outset and l've never had those overwhelming feelings of being in the wrong body. There's always been fluidity in my feelings.

\section{(Rebecca, Age 55)}

5.8 In the following quotation Amanda presents an explicit critique of the 'wrong body' and, like Rebecca, suggests that gender transition is more complex than this metaphor indicates:

The way in which some people talk about being born in the wrong body is such a cliché and to come back to components, we all have a male and a female component. [...] So 'wrong body', that's a plumbing job. That's nothing to do with the core person I am, what makes me a person.

(Amanda, Age 45)

5.9 For these participants, gender identity formation is a nuanced process, which does not necessarily signify movement across a gender binary. In the following quotation Del attempts to work through these complexities:

[...] the wrong body stuff does bother me. I think a lot of it is that our culture is wrong, and if our culture was more accepting of gender diversity, would we need to? You know, if men could wear make up and dresses, and for women if there was no glass ceiling, would it be necessary? [...]

(Del, Age 44)

5.10 Thus while the narrative of the 'wrong' body' within discourses of 'gender dysphoria' is repeated to gain surgical reconstruction, the demand for surgery may be seen to be an outcome of the social and cultural investment in a gender binary system. This is particularly significant since the medical model of transgender, which influences access to the new framework of rights, remains tied to a gender binary model.

5.11 While Prosser returns to Descartes' mind/body split, Merleau-Ponty's (1962) work offers an alternative framework through which to explore these issues of embodiment. In challenging the duality of mind/body, Merleau-Ponty theorises the intersections between the material body and the phenomenological realm to explore how the body is consciously experienced. The 'corporeal schema' indicates how the embodied agent is positioned between the subjective and the social world. For Merleau- Ponty, embodiment is not necessarily a conscious state, but may be experienced as an 'inner sense', which influences our bodily actions and responses. The intersections of the subjective, material and the social were apparent in this research when participants discussed surgery as a way of reconciling self-identity and social identity. For example, in answer to my question 'how important was surgery for you?', Dave says:

Surgery was very important. Because even without hormones, the way I presented myself and the way I dressed, people would see me as male. But because of my chest I had to bind myself up everyday and, apart from the discomfort, I just felt they shouldn't be there [...]

(Dave, Age 26)

5.12 In articulating the complex relationship between embodiment and gender identification, these narratives resonate with Freud's (1923) notion of 'bodily ego', whereby our sense of 'self develops through our sense of the body. Grosz (1994) conceptualises this as a 'psychical map', through which our formation of 'self' involves a psychical image of our body. Yet whilst the understandings and experiences of surgery of several participants in this research suggest that the material body 'matters', as Nataf argues: 'the achieved anatomy is a way of relieving the confusion and anxiety, and the body is a point of reference, not a nature' (1997: 45). Although the significance placed upon a congruent relationship between gender identity and bodily appearance is reflected by some participants, the desire for surgery is rarely a straightforward manifestation of 'gender dysphoria'. The only participant to straightforwardly articulate the 'wrong body' experience was Cheryl, who, in answer to my question 'how do you describe your gender identity?', replied 'female trapped in a male body.' (Cheryl, Age 45). Significantly Cheryl had sought medical advice from her GP only four months before our interview and was still waiting for her first appointment with a psychiatrist. Epstein's (1995) application of a Foucauldian analysis is useful for understanding the influence of a medical model upon transsubjectivities. Through medical surveillance the 'patient' is viewed as a special type of person and individual experience is lost as the person emerges as a 'medical type' (Epstein, 1995: 26). 
Thus personal accounts are written into medical discourse, which converts 'unclear subjectivity into an interpretable text, which takes precedence over the fragments of human experience' (Epstein, 1995: 29). Power is transferred from the 'speaking subject' to the 'expert' (Sharpe, 2002: 25) to sustain a 'regime of truth' (Foucault, 1980). In this way, medical case studies do not simply 'record', but work to 'produce' knowledge. As well as constructing transsubjectivities, this process regulates claims to citizenship.

\section{Claiming Citizenship}

6.1 Nadia's role in Big Brother 5 highlights the tensions apparent in question of transgender citizenship. Nadia found a place in the Big Brother house following her openness about gender transition during auditions for the show. Yet while programme makers, the media and Big Brother audiences knew about her recent transition, Nadia did not speak of transitioning to her housemates. Nadia was clearly aware that the public would be interested in her gender experience; explicitly coming out as a trans woman in her audition video. Yet in the Big Brother diary room and in subsequent media interviews she spoke of her decision not to tell her housemates in terms of being accepted as a woman: 'I wanted to enjoy it, embrace the world. I didn't want to sit around and have deep conversations or anything like that [...] I don't want to tick a box and say I'm transgender. I don't understand why people want to categorise themselves like that [...] Rather than consider themselves transgender they [trans women] should just let their personalities shine. We are women. I am a woman. If you want to get into that, you're going to be stuck most of the time talking about what you've been through, and that is the last thing I want' (Nadia Almada quoted in The Observer, 2004). Some participants in this research also articulated individual rather than transgender identities. In answer to my question 'is the term transgender relevant to you?', Tony, for example, says:

I've never thought of myself as transgender. I'm just a bloke who's gone through one or two shit things but that's all I've ever been.

(Tony, Age 39)

6.2 Narratives of moving beyond a transgender identity are characteristic of 'claims to citizenship'. Weeks et al (2001) suggest that recent social movements, particularly feminism and the lesbian and gay movement, are characterised first by moments of transgression and second by claims to citizenship. Transgression is defined as: ' [...] the constant invention and reinvention of new senses of the self, and new challenges to the inherited institutions and traditions that hitherto had excluded these new subjects' (2001: 91). The moment of transgression is followed by the claim to citizenship: '[...] the claim to equal protection of the law, to equal rights in employment, parenting, social status, access to welfare provision, and partnership rights and same sex marriage' (2001: 91). The moment of citizenship mirrors the goals of many transgender organisations and, importantly, was the lynchpin of the GRA.

6.3 Legislative changes brought by the GRA, however, show the complexities of 'claiming citizenship' for some trans people. For married people the legislation is problematic as marriages have to be annulled before a change of birth certificate is permitted. Bernadette transitioned from male-to-female fifteen years ago and remains married to her wife of forty plus years. The GRA means that Bernadette now has to choose between legal recognition as female, and her long-standing marriage. One option for Bernadette and her wife is divorce and register for a same-sex civil partnership. However, since neither Bernadette nor her wife consider themselves to be in a lesbian relationship this is a problematic choice. PfC lobbied unsuccessfully to overturn this requirement of the GRA. Claire McNab, Vice-President of PfC, summarises the outcome: 'We were left with the consequences of the government's coldly symmetrical logic: that marriage was for opposite-sex couples, and civil partnerships for same-sex couples, with no exception even for the hundred or so couples about to move from one category to the other. A harsh logic, requiring people to change their legal relationship just for logical neatness [...] (2004). As I have suggested elsewhere (Hines, 2006), transgender practices of intimacy indicate that partnering and parenting relationships are amenable to complex shifts in gendered meaning and expression. Such transformations show how intimate relationships, more broadly, are subject to on-going contest, negotiation and innovation.

6.4 Whilst these intimate narratives speak of socio-historical changes in the diversification of meanings and experiences of gender, they are muted by legislation, which denies the storyteller the recognition and rights of citizenship. Weeks et al state that '... without the claim to full citizenship, difference can never be fully validated' (2001: 91). Yet although the GRA aims to enable trans people to claim citizenship, it reinforces inequality for those who are married. Such a paradox supports Williams' claim that '... moves to recognise diversity may sometimes expose or reinforce inequality' (2004: 82). Moreover, if a 'moment of citizenship' is conceived out of the desire for inclusion, we must also bring a more radical voice into the frame.

\section{Transgressing Citizenship}

7.1 Downplayed in discussions about claims to citizenship are the sections of social movements that place 
more import on the moment of transgression than the moment of citizenship. From this perspective, the wisdom of soliciting validation is questioned. Such a position preserves the celebration of difference, and questions the merits of normativity and assimilationism. Radical gender and sexual movements such as Queer Nation and Transsexual Menace act as a cautionary reminder of the dangers of a whole-hearted liberal approach to citizenship claims. Hence those who remain 'different' are frequently constructed as 'difficult' and become further marginalised. In discussing a moment of citizenship it must not be forgotten that most recent social movements divide on the desirability of citizenship as a political goal, with many arguing that such a route inevitably leads to the subjugation of difference and transgression. This debate is apparent within transgender communities on the question of 'passing'. Whilst some trans people see passing as a prerequisite of social acceptance and inclusion, others argue against assimilating into an incomprehensible binary gender system (Stone, 1991; Feinberg, 1992, 1999; Bornstein, 1994). Research participant, Rebecca, for example, identifies as neither male nor female but as 'bigendered'. For Rebecca, rejecting the surgical route of transition has enabled increased gender fluidity:

I suppose my story has changed and matured as time has gone, and my view of my gender has appeared differently to me at different times. In terms of my place in society now in many ways I feel that I have the best of both worlds. [...] I see that as a benefit because I don't live in fear of being acknowledged as either male or female or having both characteristics should I say.

\section{(Rebecca, Age 55)}

7.2 For Del, it is also important to articulate gender fluidity:

I don't think it's linear. I think it's more like if you have [Del draws diagram]. Here we have our source and that's whoever we are and it shoots out in a more kind of radial way, so it's more like a kind of color chart and you can pick all the different colours. I think that some people are very asexual for example. They don't have a lot of sexuality and others are very sexual, and it's the same way with gender in a way. I am very gendered. I have a lot of gender and that expresses itself in a lot of different ways, whereas other people don't. They stay at one point but with me l'm kind of moving around [...] There's lots of different levels so there's not just one way in which I describe my identity. I've called myself a gender terrorist; I've called myself intersex by design, an intentional mutation, FtM, but not transsexual, and FtM is more about how people perceive me. I call myself a hermaphrodyke sometimes. I've been a lesbian or a dyke, l've been a queer dyke. Queer is probably the term I feel best describes me. I could call myself a queer trannie boy. Everything is qualified in one way or another [laugh].

$$
\text { (Del, Age 44) }
$$

7.3 Although the law now allows for movement across the binary of male/ female, the spectrums in-between male and female, such as transgendered, intersexed, bigendered and androgynous, remain outside current frameworks of citizenship. Furthermore, though the law now concedes that gender identity may change across the life-span, it remains spatially fixed. Rather than seeing gender transition as an end-point, however, many participants discussed how their understandings and experiences of gender shifted through transition. In answer to my question 'how would you describe your gender identity now?' Karen says:

I think I've probably learnt that I'm not really that different from before. I can still be quite aggressive. I still have a competitive side. Initially I went way over to the feminine side and became really girlie, which isn't me. But now l've got a bit of male and a bit of female in me which has been interesting for me and I've settled down to where I am.

\section{(Karen, Age 31)}

7.4 The narratives of participants in this research suggest that whilst identity is embodied, rather than being rigid, the relationship between gender identity and the physical body shifts and evolves through transition. Thus my research findings support Nataf's comment that: 'the form gender identity and role finally take can be more or less fixed or fluid, depending upon the individual' (1997: 20). Yet an understanding of gender as intertextual and precarious is at odds with current concepts of citizenship. Monro (2005) has discussed the pitfalls of constructing a model that pits the 'nice trans person' against the 'less nice trans people'. In this way, people who rebuff the gender binary by refusing to neatly dovetail gender presentation and gender identity (for example, bigendered trans people, butch trans lesbians, camp trans men, cross-dressers, and drag kings and queens) continue to be excluded from the rights and recognition of citizenship. In rejecting the surgical route, then, transgender people fall outside the domain of the 'deserving citizen' (Richardson, 1998). 
7.5 Weeks et al discuss debates around recognition within lesbian and gay communities as '[...] one based on boundary-defenders who argue for a social movement based on a collective identity, and boundarystrippers who argue for the deconstruction of identity and binary categories [...]' (2001: 192). Although similar themes are apparent in debates around recognition and assimilation within transgender communities, the tensions around a transgender politics of identity are more complex in that the 'boundary strippers' of gender may simultaneously act as 'boundary defenders' in arguing for the importance of a transgender (rather than transsexual) identity that denotes gender difference. There are, then, conceptual problems as well as civil inequalities in recent moves to grant trans people citizenship. Constructed upon a gender binary model, the GRA is unable to recognise the diversity of new (trans) masculinities and femininities as they are variously constructed and experienced. Hence, rather than broadening the realm of citizenship in relation to gender diversity, the Act works to reinforce a normative gender model.

\section{Conclusion}

8.1 This paper has examined issues of transgender citizenship in relation to recent social, cultural and legislative developments. Representing the civil recognition of gender transition, the GRA marks an important change in attitudes towards trans people and aims to end social exclusion. The paper has argued, however, that legislative understandings of transgender remain tied to a medical perspective. Whilst the 'claims to citizenship' of some trans people - those who have undergone surgery or who articulate 'gender dysphoria' - may be facilitated through the new framework of rights, the enduring influence of a medical model upon social and legal understandings of transgender mean that those who 'transgress' married trans people who choose not to divorce and those who construct identities outside the gender binary - remain on the margins of citizenship; residing as 'non citizens'. My findings here support Richardson's (2004) argument that social change sought through the notion of 'citizenship' tends to emphasise 'sameness' rather than equality of 'difference'. Thus the current framework of transgender citizenship still fails to account for gender diversity.

8.2 Research findings suggest that whilst some participants articulate individualism and are reluctant to position themselves as members of a collective transgender culture, others present distinct transgender identity positions that are consciously created in opposition to traditional ways of thinking about gender. These latter gender identity practices offer a challenge to political goals of assimilation; signposting a radical politics of gender transformation in which 'difference' is positioned as a site of importance and celebration in its own right.

8.3 The complexities of trans identity positions and identity politics mean that transgender citizenship is an uneven and contested terrain. As Bell and Binnie argue in their discussion of sexual citizenship: '[...] to disidentify - to remain as non-citizens - will maintain systems of exclusion and discrimination that brings real material harm to many people' (2000: 146). Whilst the GRA must be welcomed for its aim to remedy exclusionary systems for trans people, the task now is to critically deconstruct the gender binary in order to fully account for contemporary gender transformations.

\section{References}

BACK, L and Solomos, J. (eds.) (2000) Theories of Race and Racism, Routledge.

BELL, D. and Binnie, J. (2000) The Sexual Citizen: Queer Politics and Beyond, Cambridge: Polity Press.

BELL, D. (2004) 'Sexual Citizenship' in Eadie, J. Sexuality: The Essential Glossary, NY and London: Arnold.

BENJAMIN, H. (1966) The Transsexual Phenomenon

BLAIKIE, N. (2000) Designing Social Research, Cambridge: Polity Press.

BOLIN, A. (1998) In Search of Eve: Transsexual Rites of Passage, South Hadley: Bergin and Garvey.

BORNSTEIN, K, (1994) Gender Outlaws: On Men, Women and the Rest of Us , London: Routledge.

BURNS, C. (2004) @ http://wwwbigbrother.digitalspky.co.uk

BUSSEMAKER, J. and Voet, R. (1998) 'Citizenship and Gender: Theoretical Approaches and Historical Legacies', Critical Social Policy, 18 (3): 278-307.

BUTLER, J. (1994) Gender Trouble: Feminism and the Subversion of Identity , London: Routledge. 
COOPER, D. (1995) Power Struggle: Feminism, Sexuality and the State, Buckingham: Open University Press.

CROMWELL, J. (1999) Transmen and FTMs: Identities, Bodies, Genders and Sexualities, University of Illinois Press.

DALY, G. and Cowen, H.. 'Redefining the Local Citizen' in McKie, L. and Watson, N. (eds) (2000) Organising Bodies, London: Macmillan.

DUNNE, G. (1997) Lesbian Lifestyles: Women's Work and the Politics of Sexuality, London: Macmillan.

EDWARDS, R. (1993) 'An Education In Interviewing: Placing the Researcher and the Research' in Renzetti, C. M. and Lee, R. M. (eds) Researching Sensitive Topics, London: Sage.

EKINS, R. and King, D. (1996) Blending Genders: Social Aspects of Cross - Dressing and Sex Changing, London: Routledge.

ELLEN, B. The Observer, 22nd August 2004.

EPSTEIN, J. (1995) Altered Conditions: Disease, Medicine and Storytelling, London: Routledge.

EVANS, D. (1993) Sexual Citizenship: The Material Construction of Sexualities , London: Routledge.

FEINBERG, L. (1992) Transgender Liberation: A Movement Whose Time Has Come, New York: World View Forum.

FEINBERG, L. (1997) Transgender Warriors : Making History from Joan of Arc to Dennis Rodman, Beacon Press.

FOUCAULT, M. (1978) The History of Sexuality, Volume 1: An Introduction: Random House.

FOUCAULT, M. (1980) Power/Knowledge: Selected Interviews and Other Writings 1972 -1977, -New York: Pantheon.

FOUCAULT, M. (1985) The Use of Pleasure: The History of Sexuality, Vol. II, translated by Robert Hurley, Pantheon.

FREUD, S. (1923) 'The Ego and the Id.' in Strachey et al (trans.) The Standard Edition of the Complete Psychological Works of Sigmund Freud (1953-1965) London: Hogarth Press.

GREEN, R., Money, (1969) Transsexualism and Sex Reassignment

GREEN, R. (1987) 'Definition and Synopsis of Aetiology of Adult Gender Identity @ http://www.gires.org.uk/Text_Assets/Etiology_Definition.

GRIGGS, C. (1998) S/He: Changing Sex and Changing Clothes, Oxford: Berg.

GROSZ, E. (1994) Volatile Bodies: Towards a Corporal Feminism, Bloomington and Indianapolis: Indiana University Press.

HARRY BENJAMIN INTERNATIONAL GENDER DYSPHORIA ASSOCIATION'S, (2001) Standards of Care for Gender Identity Disorders, Sixth Version @ http://www.pfc.org.uk/medical/soc2001.htm.

HALBERSTAM, J. (1998) Female Masculinity, Duke Press.

HALE, J. (1997) Suggested Rules for Non-Transsexuals Writing about Transsexuals, Transsexuality, Transsexualism, or Trans_@ http://www.sandystone.com/hale.rules.html.

HAUSMAN, B. (1995) Changing Sex: Transsexualism, Technology, and the Idea of Gender, Durham \& London: Duke University Press.

HINES, S. (2006) 'Intimate Transitions: Transgender Practices of Partnering and Parenting, Sociology, 40 (2).

HOLLWAY, W. and Jefferson, T. (2000) Doing Qualitative Research Differently: Free Association, Narrative and the Interview Method, London: Sage.

JONES, L., quoted in The Observer, 8th August, 2004. 
LEWIS, G. (ed.) (1998) Forming Nation, Framing Welfare, Routledge.

LISTER, R. (1997) Citizenship: Feminist Perspectives, London: Macmillan.

MARSHALL, T. (1950) Citizenship and Social Class and Other Essays , Cambridege: Cambridge University Press.

MCNAB, C. (2004) 'Married Trans People and Civil Partnerships: Where Next?' @ http://www.pfc.org.uk/pfclists/news-arc/2004q3/msg00044.htm.

MERLEAU-PONTY, M. (1962) The Phenomenology of Perception, London: RKP.

MONRO, S. (2000) 'Theorizing Transgender Diversity: Towards a Social Model of Health', Sexual and Relationship Therapy, 15(1): 33-45.

MONRO, S. (2003) 'Transgender Politics in the UK', Critical Social Policy, 23 (4): 433-452.

MONRO, S. (2005) Gender Politics: Citizenship, Activism and Sexual Diversity, London: Pluto.

NATAF, Z. (1995) Lesbians Talk Transgender, London: Scarlett Press.

OAKLEY, A. (2000) Experiments in Knowing: Gender and Method in the Social Sciences, New Press.

PATEMAN, C. (1989) The Disorder of Women: Disorder, Feminism and Political Theory , Cambridge: Polity Press.

PHILLIPS, A. (1993) Democracy and Difference, Cambridge: Polity.

PLUMMER, K. (1995) Telling Sexual Stories: Power, Change and Social Worlds, London: Routledge.

RICHARDSON, D. (1998) 'Sexuality and Citizenship', Sociology, 32.

PROSSER, J. (1998) Second Skins: The Body Narratives of Transsexuality, Columbia University Press.

RICHARDSON, D. (2000a) 'Constructing Sexual Citizenship: Theorizing Sexual Rights', Critical Social Policy, 20: (1).

RICHARDSON, D. (2000b) 'Claiming Citizenship?: Sexuality, Citizenship and Lesbian/Feminist Theory', Sexualities: 3(2).

RICHARDSON, D. (2004) 'Locating Sexualities: From Here To Normality' Sexualities, 7(4), 391-411.

SEIDMAN, S. (1998) 'Are we all in the Closet: Notes Toward a Sociological and Cultural Turn in Queer Theory', European Journal of Cultural Studies, Vol.1.

SHARPE, A. N. (2002) Transgender Jurisprudence: Dysphoric Bodies of Law , London: Cavendish Publishing Limited.

STOLLER, R. (1975) ' Passing and the Continuum of Gender Identity' in Marmor, J. (ed.) Sexual Inversion: The Multiple Roots of Homosexuality, New York: Basic Books.

SONG, M and Parker, D. (1995) 'Commonality, Difference and the Dynamics of Disclosure in In-depth Interviewing', Sociology 29. (2).

STOLLER, R. (1968) 'The Transsexual Experiment' Vol. 11 Sex and Gender., London: Hogarth Press.

STOLLER, R. (1968). Sex and Gender (Vol. I), The Development of Masculinity and Femininity, Jason Aronson.

STONE, S. (1991) 'The Empire Strikes Back: A Posttransexual Manifesto', in Epstein, J. and Straub, K. (eds) (1991) Body Guards: The Cultural Politics of Gender Ambiguity , London: Routledge.

STYCHIN, C, (1998) A Nation By Rights: National Cultures, Sexual Identity Politics and the Discourse of Rights, Philadelphia: Temple University Press.

TURNER, B. and Hamilton, P. (eds) (1994) Citizenship: Critical Concepts, London: Routledge.

WALBY, S. (1994) 'Is Citizenship Gendered?’ Sociology, 28 (2): 379-3795. 
WEEKS, J.(1995) Invented Moralities: Sexual Values in an Age of Uncertainty, Cambridge: Polity Press. WEEKS, J. (1998) 'The Sexual Citizen’ Theory, Culture and Society, 15 (3-4_: 35-52.

WEEKS, J., Heaphy, B. and Donovan, C. (2001) Same Sex Intimacies: Families of Choice and Other Life Experiments, London: Routledge.

WEEKS, J., Heaphy, B and Donovan, C. (2004) Same Sex Intimacies: Families of Choice and other Life Experiments, Routledge.

WHITTLE, S. (2000) The Transgender Debate: The Crisis Surrounding Gender Identity, Garnet Publishing Ltd

WILLIAMS, F. (2004) Rethinking Families, London: Calouste Gulbenkian Foundation. 